\title{
FACTORS AFFECTING QUALITY IMPROVEMENT OF LIFE IN PATIENTS WITH POST-TRANSFEMORAL AMPUTATION
}

\section{NUR RACHMAT ${ }^{1 *}$, MOHAMMAD FANANI ${ }^{2}$, DARSONO DARSONO ${ }^{3}$, SUWARTO SUWARTO ${ }^{4}$}

\begin{abstract}
${ }^{1}$ Study Program of Community Development/Empowerment, Sebelas Maret University, Surakarta, Jawa Tengah, Indonesia. ${ }^{2}$ Department of Psychiatry, Medical Faculty, Sebelas Maret University, Surakarta, Jawa Tengah, Indonesia. ${ }^{3}$ Study Program of Agribusiness, Sebelas Maret University, Surakarta, Jawa Tengah, Indonesia. ${ }^{4}$ Study Program of Faculty of Agriculture, Sebelas Maret University, Surakarta, Jawa Tengah, Indonesia. Email: nurrachmat@gmail.com
\end{abstract}

Received: 30 July 2019, Revised and Accepted: 20 August 2019

\section{ABSTRACT}

Objective: The study aims to investigate the contributions of self-efficacy, motivation, religiosity, social support, optimism, and subjective well-being as factors affecting quality of life on individuals with transfermoral amputation. Through empowerment, it is expected that there will be an increase in independence and socioeconomy. The ultimate goal of the empowerment process is for independence.

Methods: This study used observational analytic with cross-sectional approach. The sample in this study was 110 post-transfemoral amputation patients. Data taken from questionnaires of self-efficacy, motivation, religiosity, social support, optimism, subjective well-being and quality of life were analyzed using structural equation modeling.

Results: There was no influence of motivation on quality of life (critical ratio $[\mathrm{CR}]=0.535<1.96$; $p=0.592<0.05$ ). There was a statistically significant positive effect of self-efficacy on quality of life ( $C R=3.082>1.96$; $\mathrm{p}=0.002<0.05)$. There was a statistically significant positive effect of religiosity on quality of life ( $C R=2.919>1.96 ; \mathrm{p}=0.004<0.05)$. There was no influence from social support for quality of life $(\mathrm{CR}=0.082<1.96 ; \mathrm{p}=0.935<0.05)$. There was a statistically significant positive effect of optimism on quality of life $(C R=2.307>1.96$; $p=0.021<0.05)$. There was a statistically significant positive effect of subjective well-being on quality of life $(C R=2.089>1.96$; $p=0.037<0.05)$.

Conclusion: The quality of life of patients with post-transfemoral amputation is positively and significantly influenced by optimism, religiosity, selfefficacy, and subjective well-being.

Keywords: Quality of life, Motivation, Self-efficacy, Religiosity, Optimism, Social support, Subjective well-being.

(C) 2019 The Authors. Published by Innovare Academic Sciences Pvt Ltd. This is an open access article under the CC BY license (http://creativecommons. org/licenses/by/4. 0/) DOI: http://dx.doi.org/10.22159/ajpcr.2019.v12i10.35136

\section{INTRODUCTION}

Amputation causes a change to the people such as physical change, social change, psychological change, and environmental change in the long term [1]. Losing one of the potential member effects reducing most of the daily activities and social interaction with others [2]. Amputation also has a big effect on human life because it causes people to lose many physical functions and abilities which are commonplace.

Although amputation aims to save the patient's life and body, there are still many things which have a negative impact on the patient. It is psychological changes. The effect of amputation is that patient senses losing self-confidence; therefore, many people lack of enthusiasm in living because they cannot act as usual due to losing their limbs. Loss of confidence will be increasingly felt if the patient previously has a high social status [3].

The quality of life in persons with disabilities automatically decreases after losing an important part of a person's body [4]. Wald argues that holistic and whole rehabilitation approaches are needed due to complex physical and psychological problems which are associated with amputation [5]. The aim of rehabilitation after amputation is to improve the mobility of people and to assist reintegrate into society [6]. The most affected attributes are physical capacity, physical, general health, social aspects, emotional aspects, and pain.

Regulation of the Minister of Health No. 22, in 2013, defines that the prosthetic orthotic is health services provided by orthotic prostheses in terms of health aids in the form of orthosis or prostheses for physical and psychological health based on science and technology [7]. The function of fake feet is to substitute the limbs which are lost and one of the goals is to help improving social status and selfconfidence of the patient [8]. The installation of prosthesis will be able to restore the patient's confidence because it can carry out daily activities without any difficulties and shame, especially for the patients with high social status [9]. People who have high social status will be placed higher in the structure of society then people with low social status because it is very meaningful for the patients to return their activities before. Therefore they use lower limb prosthesis to increase their confident [10]. Amputation affects a person's quality of life due to limitations which is caused by the functions and structures of body which inhibit the level of activity so that participation is subsequently influenced by environment and personal factors [11].

Life low quality is one of the problems for the patients with transfemoral amputation. Amputation causes the patient to adapt with different body condition and to do activity in different way. The patient uses a prosthesis to help their body so that it can be functioned further. The life quality of patient with transfemoral amputation who uses prosthesis is influenced by many things which are interested to be researched to be able to support their life quality by medical amputation team or the society who cares with diffability.

The purpose of this study was to analyze the factors that influence quality of life in patient with post-transfemoral amputation. 


\section{METHODS}

\section{Ethical approval}

This study received approval from the Ethics Committee of the Faculty of Medicine, Sebelas Maret University. Administrative clearance was obtained from the ministry of internal affairs Republic of Indonesia and National Unity and Community protection office, at district level and from PT Kuspito Prosthetic Orthotic. Respondents filled out informed consent before the study was conducted

This study used observational analytic with cross-sectional approach. The sample was 110 post-transfemoral amputation patients by simple random sampling. The data were collected by questionnaire and documentation. Data were collected using questionnaires of self-efficacy, motivation, religiosity, social support, optimism, and subjective well-being. A WHO QOL questionnaire is used to collect quality of life data. Subsequently, data were analyzed structural equation modeling.

\section{RESULTS AND DISCUSSION}

This hypothesis is tested by processing research data using SEM analysis; it is regression values (regression weights analysis of SEM). Fig. 1 shows analysis result structural equation modeling. It is tested by analyzing the value of the critical ratio (CR) and $p$ value of the data processing result compared with the required statistical limits, it is above 1.96 for the $C R$ value and it is below 0.05 for $p$ value.

\section{Path analysis with SEM}

The result shows that the proposed research hypothesis is acceptable. Table 1 shows result regression weights analysis structural equation modeling. Then, the discussion follows:

SEM analysis result shows that the CR value on the influence of motivation on the subject well-being in the table is $2.158>1.96$ with $\mathrm{p}=0.031<0.05$ so it can be stated that motivation influences subjective well-being in post-transfemoral amputation patients. It shows that the research subjects are people with disability where if they have a high motivation in themselves, they will be able to increase productivity so that it can improve the welfare of the subject. The results of this study are supported by research from Moo et al., concerning the relationship between motivation to participate and well-being among golfers in Korea [12].

The CR value on the effect of self-efficacy on subject well-being in the table is $2.166>1.96$ with $\mathrm{p}=0.030<0.05$ so that it stated that self-efficacy influences subjective well-being in post-transfemoral amputation patients. Self-efficacy allows patients to feel, think, motivate themselves, and behave in relation to their health. It can affect a motivation, a health behavior, and how much effort is spent to achieve

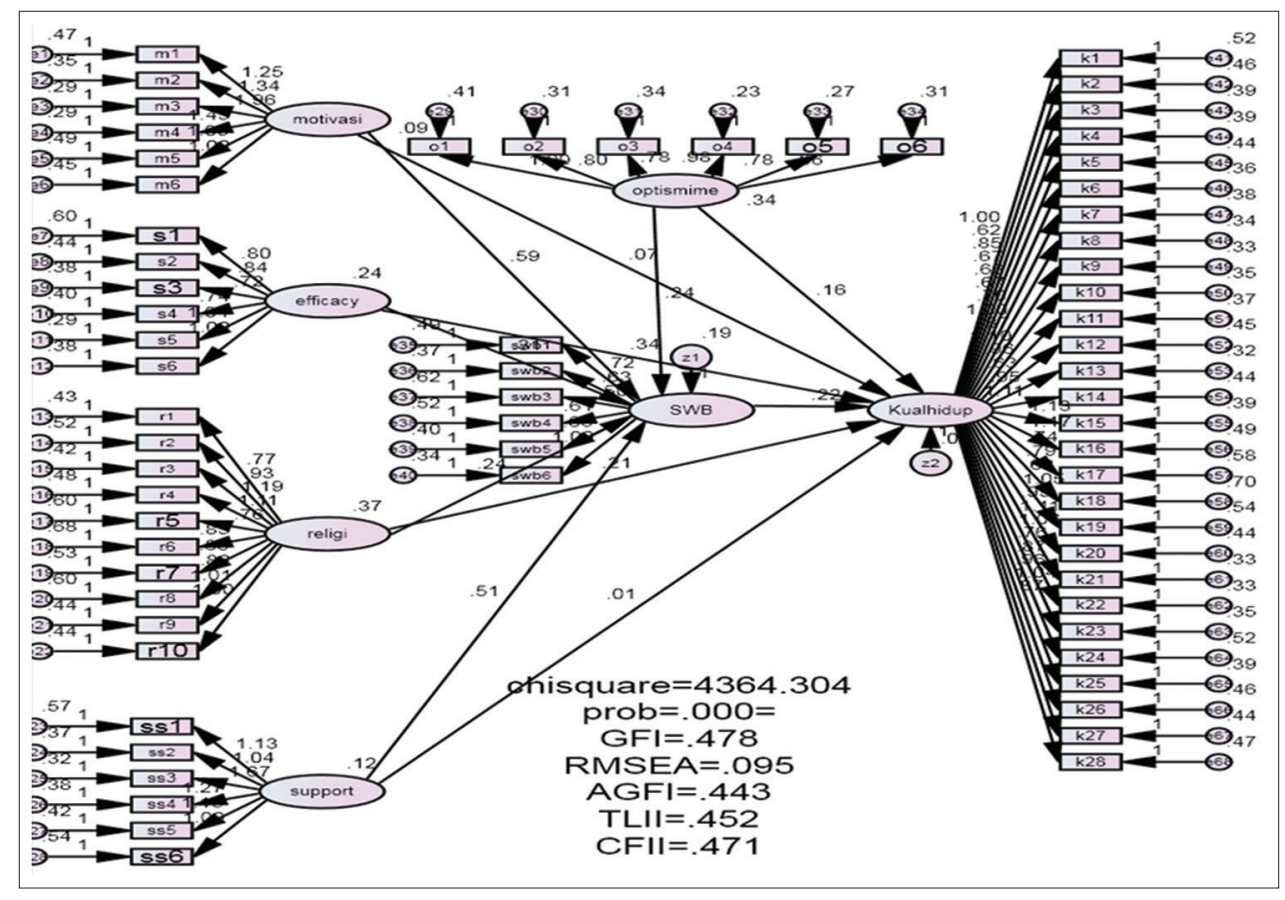

Fig. 1: Analysis result structural equation modeling

Table 1: Result regression weights analysis structural equation modeling

\begin{tabular}{llllllll}
\hline Variable & Path & Variable & Estimate & S.E. & C.R. & P & Label \\
\hline SWB & $<---$ & Motivation & 0.585 & 0.271 & 2.158 & 0.031 & Significance \\
SWB & $<---$ & Efficacy & 0.315 & 0.145 & 2.166 & 0.030 & Significance \\
SWB & $<---$ & Religious & 0.244 & 0.105 & 2.324 & 0.020 & Significance \\
SWB & $<--$ & Support & 0.514 & 0.232 & 2.212 & 0.027 & Significance \\
SWB & $<--$ & Optimism & 0.235 & 0.110 & 2.132 & 0.033 & Significance \\
Self-concep. & $<---$ & SWB & 0.220 & 0.105 & 2.089 & 0.037 & Significance \\
Self-concep. & $<---$ & Optimism & 0.159 & 0.069 & 2.307 & 0.021 & Significance \\
Self-concep. & $<---$ & Motivation & 0.072 & 0.135 & 0.535 & 0.592 & Not significance \\
Self-concep. & $<---$ & Religious & 0.212 & 0.073 & 2.919 & 0.004 & Significance \\
Self-concep. & $<---$ & Support & 0.009 & 0.116 & 0.082 & 0.935 & Not significance \\
Self-concep. & $<---$ & Efficacy & 0.345 & 0.112 & 3.082 & 0.002 & Significance \\
\hline
\end{tabular}


better health behavior, and how the patient's attitude when faced with difficulties or failures [13].

This study was supported by research from Adeyemo and Adeleye, which examines emotional intelligence, religiosity, and self-efficacy as predictors of psychological well-being among middle school adolescents [14]. The study of Katmini recommending social networking, social support, trust, high reciprocal norms need to be improved so that the individual feels, stronger support and is able to perform ANC well [15]. The Study of Rukminingsih shows the health states of EBC significantly affect HRQOL of patients. Efforts should be made to improve the quality of life of EBC patients especially in terms of pain and anxiety reduction [16].

The CR value on the influence of religiosity on the subject wellbeing in the table is $2.324>1.96$ with $p=0.020<0.05$ so that it stated that religiosity affects subjective well-being in post-transfemoral amputation patients. It means that the higher the religiosity of persons with disabilities, the more subjective well-being will be.

The CR value on the effect of social support on subject well-being in the table is $2.212>1.96$ with $p=0.027<0.05$ so it stated that social support has an effect on subjective well-being in post-transfemoral amputation patients. It means that the stronger social support from various communities will further increase subjective well-being in post-transfemoral amputation patients. The results are supported by research from Xi et al. which examines the relationship between social support and subjective well-being: Mediated by self-esteem and selfefficacy. The results showed that social support had a positive effect on subjective well-being. Self-conception mediates the relationship between social support and subjective well-being. Self-efficacy mediates the relationship between social support and subjective well-being [17].

The CR value on the effect of optimism on the subject well-being in the table is $2.132>1.96$ with $\mathrm{p}=0.033<0.05$ so that it stated that optimism affects the subjective well-being in post-transfemoral amputation patients. It means that the more optimistic a person with a disability, the sexuality will increase subjective well-being. The results are supported by research from Kreis et al. about the relationship between optimism and health-related quality of life (HRQoL). These results indicate that optimism affects the mental component of HRQoL, but not physical HRQoL [18]. Optimism is an expectation that better things which will happen than bad things in the future.

\section{CONCLUSION}

Subjective well-being of patient with post-transfemoral amputation is positively and significantly influenced by motivation, self-efficacy, religiosity, social support, and optimism.

\section{Suggestion}

It hopes that the results of this study will be able to serve as one of the considerations in the preparation of medical rehabilitation programs for people or groups of persons with disabilities in improving the quality of life.

\section{REFERENCES}

1. Horgan O, MacLachlan M. Psychosocial adjustment to lower-limb amputation: A review. Disabil Rehabil 2004;26:837-50.

2. Deans SA, McFadyen AK, Rowe PJ. Physical activity and quality of life: A study of a lower-limb amputee population. Prosthet Orthot Int 2008;32:186-200.

3. Jacobsen JM. Nursing's role with amputee support groups. J Vasc Nurs 1998;16:31-4

4. Wald J. Psychological factors in work-related amputation: Consideration for rehabilitation counsellors. J Rehabil 2004;70:6-15.

5. Sinha R, Van Den Heuvel WJ. A systematic literature review of quality of life in lower limb amputees. Disabil Rehabil 2011;33:883-99.

6. Williams RM, Ehde DM, Smith DG, Czerniecki JM, Hoffman AJ, Robinson LR, et al. A two-year longitudinal study of social support following amputation. Disabil Rehabil 2004;26:862-74.

7. Act of the Republic of Indonesia Number 4, of 1997, Concerning Disabled People; 1997.

8. Rachmat N. Pengaruh penggunaan kaki palsuterhadap kepercayaan diri pasien post amputasi kaki. J Kesehatan 2016;7:102-7.

9. Zeinali K, Masoudi R. Motivational interviews to improve nurses' motivation and self-efficacy for the use of closed suctioning system in the ICU. Int J Med Res Health Sci 2016;5:100-7.

10. Warsyah A, Wahyuni I, Widjasena B. Analisis manfaat kaki palsu (prothesa) terhadap aktivitas fisik pada kaum difabel (tuna daksa) di paguyuban penyandang cacat jasmani dan wirausaha raden. J Kesehatan Masyarakat 2014;2:170-5.

11. Ustün TB, Chatterji S, Bickenbach J, Kostanjsek N, Schneider M. The international classification of functioning, disability and health: A new tool for understanding disability and health. Disabil Rehabil 2003;25:565-71.

12. Moo LY, Gun LY, Gil SB, Suk PH. How participation motivation affects the psychological and subjective well-being of Korean golfers. Indian J Public Health Res Develop 2018;9:1362-7.

13. Faltas SF, Ameen DA. Self-Eficacy of Patients with Lower Limb Amputation: Nursing Guidelines. 12 $2^{\text {th }}$ International Congress Integration of Scientific Research, Education Evidence Based Practice in Nursing; 2015.

14. Adeyemo DA, Adeleye AT. Emotional intelligence, religiosity and selfefficacy as predictors of psychological well-being among secondary school adolescents in Ogbomoso, Nigeria. Eur J Psychol 2015;4:949-65.

15. Katmini K, Murti B, Oepomo TD, Anantanyu S. Path analysis on the effect of social capital on the empowerment of pregnant women in preeclampsia prevention using preceede-proceede in Kediri East Java, Indonesia. Asian J Pharm Clin Res 2017;11:271-3.

16. Rukminingsih F, Andayani TM, Rahmawati F, Widayati K. Healthrelated quality of life in early breast cancer patiens with hormone responsive. Int J Pharm Pharm Sci 2018;10:47-9.

17. Xi X, Wang Y, Jia B. The Effect of Social Support on Subjective Wellbeing: Mediator Roles of Self-esteem and Self-efficacy. Advances in Social Science, Education and Humanities Research; 121. $3^{\text {rd }}$ International Conference on Humanities and Social Science Research. 2017.

18. Kreis S, Molto A, Bailly F, Dadoun S, Fabre S, Rein C, et al. Relationship between optimism and quality of life in patients with two chronic rheumatic diseases: Axial spondyloarthritis and chronic low back pain: A cross sectional study of 288 patients. Health Qual Life Outcomes 2015;13:78. 